\title{
The Anti-Jewish Narrative
}

\author{
Nathan Cofnas $^{1}$ (D)
}

Received: 3 September 2020 / Accepted: 5 January 2021 / Published online: 3 February 2021

(c) The Author(s) 2021, corrected publication 2021

\begin{abstract}
According to the mainstream narrative about race, all groups have the same innate dispositions and potential, and all disparities - at least those favoring whites - are due to past or present racism. Some people who reject this narrative gravitate toward an alternative, anti-Jewish narrative, which sees recent history in terms of a Jewish/ gentile conflict. The most sophisticated promoter of the anti-Jewish narrative is the evolutionary psychologist Kevin MacDonald. MacDonald argues that Jews have a suite of genetic adaptations - including high intelligence and ethnocentrism - and cultural practices that lead them to undermine gentile society to advance their own evolutionary interests. He says that Jewish-designed intellectual movements have weakened gentile identity and culture while preserving Jewish identity and separatism. Cofnas recently argued that MacDonald's theory is based on "systematically misrepresented sources and cherry-picked facts." However, Cofnas gave short shrift to at least three key claims: (a) Jews are highly ethnocentric, (b) liberal Jews hypocritically advocate liberal multiculturalism for gentiles/gentile countries but racial purity and separatism for Jews/Israel, and (c) Jews are responsible for liberalism and mass immigration to the United States. The present paper examines these claims and concludes that MacDonald's views are not supported.
\end{abstract}

Keywords Jews $\cdot$ Liberalism $\cdot$ Ethnocentrism $\cdot$ Multiculturalism $\cdot$ Mass immigration · Alt-right

\section{Introduction}

Mainstream moral/political discourse is built around the narrative that all groups have the same innate dispositions and potential, and all differences - at least those favoring whites - are due to past or present white racism. Establishment intellectuals and media ignore or misrepresent facts that go against the narrative. They trumpet a small number of exceptional, narrative-supporting incidents as if they represented

Nathan Cofnas

nathan.cofnas@balliol.ox.ac.uk

1 Balliol College, University of Oxford, Oxford OX1 3BJ, UK 
general trends. The statistics they cite to support the narrative often have better alternative explanations.

Many promoters of the white-racism narrative are sincere, and they aren't necessarily bad at reasoning in general. But narratives shape our expectations, which influence how we process information. In this way, narratives in politics are similar to paradigms in science. A scientist who sees the world through the lens of a paradigm is often blinded to certain facts-namely, facts that cannot be made sense of from the perspective of the paradigm (Kuhn 1962). If you think white racism explains everything, you tend to see it even when it isn't there. When you do find a real example of white racism you may be inclined to blow it out of proportion. You glaze over facts that don't jibe with the narrative, and dismiss anyone who confronts you with counternarrative facts (aka "hate facts") as a racist.

Some degree of narrative thinking is probably unavoidable in politics, just as paradigm thinking is unavoidable (and may even be essential) in science. But narratives and paradigms can fit the facts better or worse. They can be more or less accurate. The mainstream narrative about race is untenable when certain facts are confronted honestly (see, e.g., Gottfredson 2005; Sesardić 2018; Warne 2020; Winegard et al. 2020), but that is not the topic of this paper and I cannot undertake a proper defense of that claim.

People who reject the anti-white narrative-especially those who consider themselves "race realists"- sometimes gravitate toward an alternative, anti-Jewish narrative, which sees recent history in terms of a Jewish/gentile conflict. The most sophisticated promoter of the anti-Jewish narrative is retired California State University, Long Beach psychology professor Kevin MacDonald. In his words:

Jewish-dominated intellectual movements were a critical factor (necessary condition) for the triumph of the intellectual left in late twentieth-century Western Societies....[I]ndividuals who strongly identified as Jews have been the main motivating force behind several highly influential intellectual movements that have simultaneously subjected gentile culture to radical criticism and allowed for the continuity of Jewish identification. (MacDonald 1998: 17, 213)

Advocates of the anti-Jewish narrative may disagree about some details, but they would all probably agree with the following core ideas: (a) the liberal multicultural ideology prevailing in the West was largely designed to serve Jewish interests related to group continuity, racial purity, and Israel, (b) in the absence of Jewish influence, the West would not have become liberal/multicultural (i.e., Jews were a "necessary condition"), and (c) there are some significant biological and/or cultural differences between Jews and white gentiles that explain why Jews were motivated-and how they were able-to impose a self-serving ideology on gentiles.

According to MacDonald, Jews have a suite of genetic adaptations and cultural practices that constitute a "group evolutionary strategy." Their genetic adaptations include high intelligence (he estimated mean Ashkenazi IQ to be 117, though recent studies suggest 110-112; Cochran et al. 2005; Lynn and Kanazawa 2008) and ethnocentrism. He argues that intelligent, ethnocentric Jews created 
liberal intellectual and political movements to promote Jewish interests at the expense of gentiles.

In 2018 I published the first academic critique of MacDonald, in which I proposed the "default hypothesis" to explain Jewish overrepresentation in liberal intellectual movements: Jews are overrepresented in all intellectual movements and activities that are not overtly anti-Semitic primarily because they have high mean IQs. In recent history, Jewish involvement in politics has skewed left because a higher proportion of right-wing than left-wing movements were overtly anti-Semitic. But Jews have also been overrepresented in the leadership of nonanti-Semitic right-wing movements (Cofnas 2018).

The default hypothesis provides a single explanation for why Jews are overrepresented in intellectual activities that have nothing to do with politics, like mathematics, medicine, and chess, and why they are often the leaders of political movements with violently opposing aims. Plenty of socialist leaders are Jewish, but almost all of the most prominent libertarian leaders are Jewish, too (Friedman, Mises, Nozick, Rand, Rothbard, etc.). The Anti-Defamation League (ADL) is leading the charge to censor politically incorrect speech, but the most prominent pro-free speech organization in the US - the Foundation for Individual Rights in Education (FIRE) — was founded by Jews (Alan Charles Kors and Harvey Silverglate). Right-wing movements in the twentieth century were disproportionately anti-Semitic, so it's no surprise that Jews were less well-represented in leadership positions on the right.

Consistent with the default hypothesis, I found that Jewish intellectuals have not been especially concerned with their ethnic interests compared with gentile intellectuals. The influential movements discussed by MacDonald were not designed to advance Jewish interests, and in fact many of them opposed Jewish interests (as conceived by MacDonald). The roots of modern leftism go way back in European history, and the influence of gentile intellectuals and activists was more than sufficient to drive recent political trends.

A lot of my debate with MacDonald focused on the motivations of specific, influential Jewish intellectuals such as Freud, Boas, and the Frankfurt School theorists. In many cases, MacDonald's evidence that these people were "strongly identified" Jews who "saw their work as furthering specific Jewish agendas" boils down to little more than insinuations based on the fact that they were Jewish and perhaps condemned the Holocaust. MacDonald never mentions that many of them opposed Jewish interests (as he conceives them) by advocating open borders for Israel, calling for the dissolution of the Jewish community, and so on. Occasionally he imagines evidence based on nothing at all, as when he falsely says that Karl Marx held that "Judaism, freed from the principle of greed, would continue to exist in the transformed society after the revolution" (MacDonald 1998: 54). As I observed, Marx never said anything like this, and in fact he said the opposite, namely, the Jew would be "impossible" in a socialist society that "abolish[ed] the preconditions for huckstering" (Cofnas 2018: 149). (MacDonald (2018b) acknowledged that his claim about Marx was inaccurate, but responded by pointing out a typo in Cofnas (2018), which he apparently sees as a comparable error.) 
Here I want to approach this topic from a different angle. My goal is not to make a comprehensive case that the anti-Jewish narrative is wrong, but to point out some counternarrative facts and to highlight the biased way in which Jews are portrayed by MacDonald and other anti-Jewish commentators. I focus on three specific issues:

(a) Are Jews particularly ethnocentric?

(b) Do liberal Jews hypocritically advocate multiculturalism for gentiles/gentile countries but racial purity and separatism for Jews/Israel?

(c) Are Jews responsible for liberalism and mass immigration?

My answers to these questions are (a) the evidence suggests Jews are not particularly ethnocentric, (b) liberal Jews typically advocate similar policies for Jews/Israel and gentiles/gentile countries, and (c) the West was on a liberal trajectory with or without Jews, and Jews were not responsible for mass immigration to the US.

This should not be misinterpreted as a claim that Jews are exactly the same as white gentiles, or that they're just like high-IQ, urban white gentiles. All groups differ from each other in interesting ways, reflecting their evolutionary and cultural histories. But, in general, anything unusual about Jewish political behavior is mostly a predictable reaction to their historical circumstances, and can be explained without positing a conspiracy or "group evolutionary strategy." For example, given that they were the victims of genocide, it was inevitable that some Jews would exploit their victimhood status to advance their personal interests or political agenda. It was inevitable that there would be an Abe Foxman (the Jewish Al Sharpton) and an ADL to capitalize on guilt about the past. We also do not need to posit a group evolutionary strategy to explain why Jews tend to be less well represented in political movements that are anti-Jewish, which call for Jews to be second-class citizens, expelled, or killed.

\section{Why Does it Matter?}

It is important to come to terms with and think through the moral implications of human diversity (Cofnas 2020). The conflation of legitimate science on race differences (Winegard et al. 2017, 2020) with pseudoscience about Jews is a major barrier preventing this from happening. The former can seem discredited through its association with the latter. People who are taken in by the pseudoscience, despite thinking of themselves as "race realists," end up with a picture of the world that is not "realist" at all. A clear distinction should be made between scholars like Arthur Jensen and Linda Gottfredson on the one hand and Kevin MacDonald on the other. Jensen et al. have a long track record of making successful predictions and claims that are supported by multiple lines of evidence (Winegard et al. 2020). MacDonald has made exactly one empirically testable prediction, which turned out to be wrong (more on that below).

I'm addressing this question-did Jews create liberal multiculturalism to advance their ethnic interests?-from a neutral scientific perspective. I'm not commenting 
on whether or in what ways this ideology is good or bad, or what the moral implications of group differences might be.

\section{Jewish Ethnocentrism}

The anti-Jewish narrative assumes that Jews are more ethnocentric than white gentiles, and that the purpose of liberal multiculturalism is to undermine group continuity among gentiles while cultivating it within the Jewish community and in Israel. MacDonald and other anti-Jewish commentators misrepresent or ignore all the counternarrative evidence showing that liberal Jews have little interest in group continuity, and generally support the same multicultural policies for white gentiles/ gentile countries and Jews/Israel.

The only empirically testable prediction MacDonald ever made concerned Jewish demographic trends. He wrote in his book, The Culture of Critique: "An important consequence-and one likely to have been an underlying motivating factor in the countercultural revolution - may well be to facilitate the continued genetic distinctiveness of the Jewish gene pool in the United States" (MacDonald 1998: 318). This prediction makes sense if you assume that Jews are a singularly ethnocentric group living in a society designed specifically to promote Jewish continuity and racial purity. But it did not pan out. As MacDonald (2018b) wrote in his reply to my paper: "I acknowledge very high intermarriage rates for Jews in the U.S. and that my projections of the Jewish demographic future in America, made 20 years ago on the basis of my reading, are not holding up."

What are the "very high" intermarriage rates? Jews have the highest intermarriage rate of any religious group in the United States (Riley 2013). Jews who avoid intermarriage - the Orthodox - are mostly right-wing extremists with little interest in national politics. The vast majority of Jews who promote radical ideologies are either Reform or religiously unaffiliated. According to a Pew Research Center survey in 2013, 50\% of Reform and $69 \%$ of unaffiliated Jews report being married to a gentile (Pew Research Center 2013: 37). Some unknown number of Reform marriages are between Jews and gentiles who underwent nominal Reform conversions, so the real intermarriage rate is higher-probably considerably higher.

Usually a failed prediction is a mark against a theory, but not for MacDonald. Although he described intermarriage as "defection" in the 2002 preface to The Culture of Critique (MacDonald 2002: xxii), he now says that high intermarriage rates support his theory, and may even be part of the group evolutionary strategy: "intermarriage and conversion have benefits for the Jewish community..., including the advantages of marrying into prominent non-Jewish families, such as the families of presidents Trump and Clinton" (MacDonald 2018b). But even if it's theoretically possible that Jews could benefit as a group from some strategic marriage alliances with powerful gentiles, like Esther marrying King Ahasuerus in ancient Persia, this could not explain intermarriage rates of well over 50\% (possibly upwards of $70 \%$ among liberal Jews) (see Cofnas 2019). And it's silly to think that most of these marriages are strategic. Jared Kushner married Ivanka Trump in 2009, long before anyone expected his father-in-law to become president, and his brother, Joshua 
Kushner, married a Victoria's Secret model who (like Ivanka) converted to Judaism. In a defense of MacDonald, Dutton (2020: 266) argues that, while "[i]t is true that ethnocentrism motivates people to marry within their identity group," we should compare intermarriage rates with what would be "expected if mate choice were random." Since Jews are $1.9 \%$ of the American population, "for Jews, the probability of meeting another Jew, assuming even distribution of religions [is] 0.036 percent." By "dividing the actual in-marriage rate by the rate expected by chance," Dutton concludes that "Jewish ethnocentrism was 49 times that of mainline Protestant ethnocentrism." (Actually, if marriages were random, the probability for Jews of meeting another Jew would be $1.9 \%$, not $0.036 \%$. 0.036 is the percentage of all marriages in the population that would be between two Jews.).

Members of all human groups are ethnocentric to varying degrees. The question is not whether ethnocentrism exists in Jews at all, but whether it exists to a significantly greater degree than among white gentiles, and is a major motivating force for liberal Jews. There are surely a number of reasons why Jews marry each other at a rate greater than chance: they are concentrated in some of the same areas, are disproportionately represented at some of the same universities and in the same professions, share similar cultural experiences and (probably) personality traits, often share religious beliefs, and they are not necessarily favored as marriage partners by all gentiles. In addition, some Jews prefer to marry other Jews because they are ethnocentric. But, again, the anti-Jewish narrative says that liberal Jews are highly ethnocentric compared to other groups, particularly white gentiles. This claim is not supported by Jews having an intermarriage rate that, combined with low fertility, will lead the liberal Jewish population to nearly disappear in another generation or two. Although MacDonald, Dutton, and others have come up with post-hoc explanations for this phenomenon to square it with the theory of high Jewish ethnocentrism, no one thought such high intermarriage rates would be a sign of ethnocentrism before the fact.

According to the anti-Jewish narrative, Jews want multiculturalism for thee, not for me. In reality, liberal Jewish leaders enthusiastically promote multiculturalism and multiracialism within the Jewish community and in Israel (Cofnas 2019: 146-147). An article published on the Union for Reform Judaism's official website explains:

We're a global, multiracial people that's growing more racially and ethnically diverse through interfaith and interracial marriage, conversion, and adoption. In the United States, February is Black History Month. It is one among many opportunities for us to acknowledge and reflect upon our collective racial and ethnic diversity, and learn more about the experiences of Jews of AfricanAmerican descent in particular. (Baskin 2016; quoted in Cofnas 2019: 146)

It only takes a few minutes browsing Reform Jewish literature to discover that "diversifying" the Jewish community is one of the movement's main priorities. This is routinely ignored or distorted by advocates of the anti-Jewish narrative. For example, MacDonald (2002: xxii) wrote that "Recent guidelines for Reform Judaism emphasize traditional practices of conversion, such as circumcision, that are likely to minimize converts, and proselytism is explicitly rejected." As I pointed out, this is 
a complete misrepresentation (Cofnas 2019: 146). Circumcision was recognized as an optional practice. According to MacDonald's own source for his claims about the guidelines:

Rabbi Shapiro [chairman of the conference's committee on conversion] said the guidelines were important for ending the traditional requirement that a rabbi discourage a potential convert. Still, conference officials said the guidelines were meant to emphasize the movement's receptivity to converts, not an interest in proselytizing. (Niebuhr 2001-italics added)

\section{Israel}

The anti-Jewish narrative assumes that liberal Jews support Israel as a Jewish ethnostate while advocating multiculturalism and open-borders for gentile (especially white gentile) countries. In reality, Jewish liberals typically promote similar multicultural policies for Israel as they do for other countries.

I pointed out that many of MacDonald's own examples of Jewish intellectual activists, such as Frankfurt School theorists Erich Fromm and Herbert Marcuse, either opposed Israel's existence or called for multiculturalism and open borders for Israel (Cofnas 2018). MacDonald (2018b) brushed these observations off with the assertion-for which he had no supporting evidence-that "different Jews see Jewish interests differently." If your argument is that "different Jews see Jewish interests differently," no matter what a Jew does you can always say it's motivated by his conception of Jewish interests. But this was not the position he originally took in The Culture of Critique, where he wrote that "there is a broad Jewish consensus on such issues as Israel" (MacDonald 1998: 305), and (in the preface to the 2002 edition) described "support for Israel" as serving Jewish "ethnic interests" without qualification (MacDonald 2002: xxii).

Advocates of the anti-Jewish narrative, including MacDonald, often claim that immigration to Israel is restricted to Jews. This is false. As I pointed out, since 1970, Israel will give automatic citizenship to anyone with one Jewish grandparent and their non-Jewish spouse and children (Cofnas 2018: 152; Israel Ministry of Foreign Affairs 2013). We don't know the exact number, but hundreds of thousands of gentiles have been granted Israeli citizenship because of this policy. According to the Times of Israel, "there are already some 400,000 people, mostly from the former Soviet Union, living in Israel who are not considered Jewish by the Chief Rabbinate" (Sokol 2019). Halachic Jews (i.e., those who are Jewish according to Jewish law) make up 65\% of Israel's total population. Although MacDonald knows that immigration to Israel isn't restricted to Jews, he repeated his false claim in an interview in 2019, saying: "Israel has very restrictive immigration laws, effectively limiting immigration to Jews who can prove their Jewish ancestry" (Canlorbe 2019).

A report by the Israeli organization Hiddush (which promotes "religious diversity" and conversion) claimed that $86 \%$ of immigrants to Israel between 2012 and 2019 were not halachically Jewish (Sharon 2019). The Interior Ministry said there was an "error" in the data they had provided to Hiddush, and the true number of 
non-Jewish immigrants was 37\%. But the 37\% figure was based on the "current status" of immigrants (i.e., their post-immigration identity) rather than their status when they arrived in Israel. Whatever the true statistic is, immigration to Israel is not limited to Jews either legally or in practice, and a substantial proportion-possibly a majority—of immigrants aren't halachically Jewish and many don't have any Jewish ancestry at all.

In The Culture of Critique, MacDonald (1998: 320) wrote that "American Jews have had no interest in proposing that immigration to Israel should be...multiethnic." This is plainly false. In the 1980s, liberal Jews in the US pushed for the immigration of large numbers of Ethiopians whose halachic status as Jews is highly controversial and who have no genetic relation to other Jewish populations (Lucotte and Smets 1999). As of 2013, Israel had a rapidly growing population of more than 135,000 Ethiopians (Myers-JDC-Brookdale Institute 2015). Alan Dershowitz, whom MacDonald specifically identifies as a Jewish ethnic activist, played a leading role in pressuring the Israeli government to accept more "Jews of color." In Dershowitz's (2007) words: "we have filed lawsuits, helped raise money, pressured leaders, and argued in the court of public opinion in favor of increased [multiethnic] immigration into Israel."

When I observed that American Jews pushed for Ethiopian immigration to Israel (Cofnas 2018: 152-153), MacDonald (2018b) responded that Ethiopians

constitute only a little over $2 \%$ of the population and thus may not be seen as a serious threat to the demographic status quo. And it's worth pointing out that Ethiopian Jews have not been welcomed by many Israelis and remain on the fringes of Israeli society. A BBC report from 2015: "when they arrived in Israel, these distinctive people faced appalling discrimination, racism and a lack of empathy for their hardships in Ethiopia and during their journey to Israel....Many in the religious establishment even dared to question their Judaism."

Imagine if $I$ made an argument like that. Suppose a Jewish organization wanted to bring seven million Ethiopians to the US, and I said, Seven million constitute only a little over $2 \%$ of the US population, and thus may not be seen as a serious threat to the demographic status quo. And it's worth pointing out that Ethiopians have not been welcomed by many Americans and remain on the fringes of American society. A New York Times report said that Ethiopians in America face appalling discrimination. MacDonald would dismiss that argument as ridiculous.

\section{Liberalism and Immigration}

As noted, the anti-Jewish narrative says that Jews were a "necessary condition" (to use MacDonald's phrase) for the triumph of liberal multiculturalism. According to MacDonald's version of history, gentiles lived in "hierarchic harmony" (MacDonald 1998: 315) until Jews like Freud and Boas launched their intellectual assault to undermine the happy system. 
I have already addressed some of MacDonald's distorted history (Cofnas 2018). Many of the ideas he attributes to Jews were given their modern formulation by Rousseau and other gentile intellectuals in the eighteenth century, and first implemented in the (gentile-led) French Revolution. The origins of race denial, blank slatism, Noble Savage envy, and socialism go back centuries or even millennia (cf. Pinker 2002). But movements like the French Revolution, Christian abolitionism, the Social Gospel Movement, anarchism, early behaviorism, and French existentialism play no role in anti-Jewish pseudohistory.

In the last several decades-at least until recently-the whole world has been drifting toward liberalism, and Western countries in particular have been adopting increasingly extreme forms of radical multiculturalism. One challenge for the theory that Jews are responsible for all of this is that the most liberal Western countries are those where Jews are relatively small in number and influence. By some measures, Sweden is the most extreme liberal country in the world. David Schwarz (pro-multiculturalism op-ed writer in the 1960s; see Tawat 2019) and Barbara Lerner Spectre notwithstanding, Jews are less than $0.2 \%$ of the population of Sweden, and have very little influence - certainly far less influence than in places like the US and the UK. Yet the Swedes took egalitarianism (Barry 2018), feminism/gender theory (Söderlund and Madison 2015), multiculturalism (Tawat 2019), and open borders (Traub 2016) to extremes beyond any other country. In recent years, Germany under Angela Merkel led the push for multiracial immigration to Europe. According to Vox, Jews are such a small percentage of the population of Germany that "most Germans have never met a Jewish person" (Beauchamp 2016).

What about in America, where, shall we say, most people have met a Jew? Or, to put it differently, where Jews do have a lot of influence? Let's consider the Jews' role in mass immigration to the US, which is a major issue among proponents of the anti-Jewish narrative.

MacDonald (1998: chapter 7) devotes a chapter of The Culture of Critique to arguing that Jews are responsible for America's liberal immigration policies. He describes the Immigration and Nationality Act of 1965, which removed national-origin quotas and established family unification as a primary consideration for awarding visas, as "the ultimate triumph of the Jewish policy on immigration." He says: "The 1965 law is having the effect that it seems reasonable to suppose had been intended by its Jewish advocates all along: The Census Bureau projects that by the year 2050, European-derived peoples will no longer be a majority of the population of the United States."

As always, MacDonald's version of history is tendentious, highlighting liberal Jews, making unsupported speculations about their motives, and ignoring or downplaying the role played by gentiles. He says that, in the century leading up to the 1965 immigration law,

Jewish groups opportunistically made alliances with other groups whose interests temporarily converged with Jewish interests (e.g., a constantly changing set of ethnic groups, religious groups, pro-communists, anticommunists, the foreign policy interests of various presidents, the political need for presidents to curry favor with groups influential in populous states in order to win 
national elections, etc.). Particularly noteworthy was the support of a liberal immigration policy from industrial interests wanting cheap labor.

This is a mealy-mouthed way of saying that there were powerful gentile groups with the same position on immigration as the Jewish groups. Most commentators attribute the 1965 law to John F., Robert, and/or Ted Kennedy. In MacDonald's version of the story, the name "Kennedy" appears only one time, where he refers to "the Kennedy and Johnson administrations" being "prodded...to action" by the American Jewish Committee "in conjunction with like-minded organizations."

In a letter published in the Wall Street Journal, MacDonald (2018a) wrote: "Far from being unusual, my view of the role of Jewish organizations [in shaping US immigration policy] is shared by, e.g., University of California, Santa Barbara historian Otis Graham and Vanderbilt University historian Hugh Davis Graham." In his reply to my paper, MacDonald (2018b) quoted the relevant passage from Hugh Davis Graham's book, Collision Course: The Strange Convergence of Affirmative Action and Immigration Policy in America:

Most important for the content of immigration reform, the driving force at the core of this movement, reaching back to the 1920s, were Jewish organizations long active in opposing racial and ethnic quotas. These included the American Jewish Congress, the American Jewish Committee, the AntiDefamation League of B'nai B'rith, and the American Federation of Jews from Eastern Europe....To the public, the most visible evidence of the immigration reform drive was played by Jewish legislative leaders, such as Representative Celler and Senator Jacob Javits of New York. Less visible, but equally important, were the efforts of key advisers on presidential and agency staffs. (Graham 2002: 56-57)

So there you have it. MacDonald's "view of the role of Jewish organizations is shared" by mainstream historian Hugh Davis Graham. Or is it?

The passage about Jewish influence quoted in isolation gives a highly misleading picture of Graham's position. On the one hand, Graham is clear that "ethnic and religious groups" (ibid.: 58), including Jews and Catholics, were influential opponents of the national-origins quotas, and that Jews were particularly effective. Jews did play a role in the 1965 law. On the other hand, Graham says that, in the wake of the civil rights movement and political developments that coincided with Lyndon B. Johnson's election, “[a]bolishing that system [i.e., the national-origins quotas] seemed an idea whose time had come" (ibid.: 61). He explains that "[t]he immigration system constructed in the 1920s...was threatened by growing evidence that it no longer worked" (ibid.: 53). In the years leading up to 1965, an "incoherent patchwork of special government measures" had already been established to circumvent the national-origins quotas (ibid.: 53-54). Between 1945 and 1960, Presidents Truman and Eisenhower used "executive parole authority" to admit 700,000 refugees outside the quota system (ibid.: 54). "Congress...responded to the...political and cold war pressures by expanding the use of special statutes that worked outside the annual immigration quotas." In the 1950s, "the Bracero program imported on average 360,000 low-wage workers a 
year from Mexico alone," which "produced a deepening channel of migration and expanding lodgments of permanent settlement" in the US.

Between 1945 and 1965, more than 40 percent of all immigrants came to America from the Western hemisphere, which continued to be exempt from the quota limitations. As a result of these patchwork measures, by 1960 fully two-thirds of all immigrants, many of them refugees, entered the United States each year without a quota number....In the decade 1955-65, almost a million immigrants came to America with nonquota visas. (ibid.: 54)

It's important to note that the main purpose of the 1924 bill that established the national-origins quotas was to limit immigration from Eastern and Southern Europe. As Graham says:

immigrants from Mexico, Central and South America, the Caribbean, and Canada [were] exempt from quotas....Ironically, the national origins quota system curbed immigration from Europe but not from Latin America or the Caribbean. (ibid.: 46)

Immigrants of African and Hispanic ancestry continued to come to the United States in significant numbers from the Caribbean and Latin America because the Western Hemisphere was excluded from quota systems or caps. Even after the sharp restrictions of 1921 and 1924, immigration law in the late 1920s admitted an average of 287,000 immigrants a year, chiefly because of the Western Hemispheric exclusion. (ibid.: 42)

Kennedy's election in 1960 "ensured that immigration reform, though not a priority for the new administration, would find a place on the new president's agenda" (ibid.: 55). In 1965, Johnson was president, and Democrats controlled both the Senate (68-32) and the House (295-140). Graham comments: "These circumstances, especially the egalitarian thrust from the civil rights movement, virtually ensured that the 89th Congress would be pressed by the White House and the congressional leadership to abolish the national origins quota system in 1965" (ibid.: 56).

MacDonald (2018b) claims that Graham agrees with him that Jews were a "necessary condition" for the 1965 law and abolishing the national-origins quotas, but this is not supported when we consider Graham's argument in its totality. It's true that organized Jewry strongly opposed the national-origins quotas. But the quota system was becoming an anachronism. Legislators were already circumventing the quotas, the civil rights movement had made people sensitive to racial discrimination, and assimilated white Americans with increasingly mixed European backgrounds no longer assigned much significance to distinctions among different groups of Europeans. In the absence of Jewish influence, maybe the quotas would have lasted a few years longer, but their ultimate demise was inevitable.

Regarding the intentions of the proponents of the 1965 law, Graham unequivocally disagrees with MacDonald's theory that Jews "intended" to make whites into a minority. Graham is emphatic that the demographic consequences of the law were unintended. Graham (2002: 10) says: "Despite repeated pledges, and by all evidence despite sincere beliefs, by immigration reform leaders that the 1965 legislation would 
not significantly change the number or origin of immigrants, the 1965 law led to a tidal wave of immigration...." How could the immigration-reform leaders have made this miscalculation? "Given generally low levels of immigration since the 1920s, American policymakers had no experience with the 'chain immigration' the expanded family reunification preferences would invite" (ibid.: 59). MacDonald (1998) never provides any direct evidence that the Jewish opponents of the national-origins quotas "intended" to make whites into a minority, simply asserting that it is "reasonable to suppose" this. Graham's more objective analysis suggests otherwise. Even the authors of the legislation were surprised by some of its immediate consequences. According to Graham (2002: 94-95): "Emanuel Celler himself, disturbed by the steep decline of European immigration, introduced a bill to allow higher immigration from Ireland, Britain, and the Scandinavian countries, which he said had suffered from 'unintentional discrimination' as a result of his own law."

In recent years, mass nonwhite immigration has become an end in itself for many liberals. But the evidence presented by Graham suggests that the (Jewish and gentile) advocates of the 1965 immigration law did not foresee or intend its consequences. Mass immigration began as an accidental byproduct of policies that were intended by their advocates to be largely symbolic.

\section{Jews Are Not the Same as White Gentiles}

Like all groups, Jews are influenced by their unique historical circumstances and cultural background. We should not expect Jews to be the same as white gentiles, or the same as urban white gentiles with IQ 110-112. The mere discovery that differences between Jews and white gentiles persist after controlling for IQ does not necessarily mean that Jews have a group evolutionary strategy, that Jews are especially ethnocentric, or that the reigning political ideology was created by Jews to advance their interests at the expense of gentiles.

For one-and-a-half millennia, Jews were a religious minority, and often conspicuously economically successful. All successful minorities have aroused hostility from the majority populations and were used as scapegoats by those in power. Overseas Chinese in Southeast Asia and Indians in Africa have had similar experiences. Jews' recent history of persecution surely has some influence on their attitudes and behavior, and how they're perceived and treated. The mere fact that Jews are influenced in some way by their history does not support the strong claims that underlie the antiJewish narrative.

Sometimes the fact that Jews disproportionately vote Democrat in the United States is held up as evidence for the group evolutionary strategy, but this line of argument has serious problems. First, the Republican Party is much more favorable to Jewish interests on almost every key issue: Israel, taxes, affirmative action, and so on. A large part of the Republican base (evangelical Christians) literally believe they have a religious obligation to support Jews and Israel. Second-and consistent with the first point-Jews who really do care about Jewish interests, namely, the Orthodox, now vote majority Republican (Sales and Adkins 2020). Third, at least until Trump, the Democratic and Republican parties had essentially identical policies on 
immigration and multiculturalism. Fourth, the argument that Jews voting Democrat supports the anti-Jewish narrative is disingenuous. The same people who make this argument say that the Republican Party is controlled by Jews just like the Democratic Party. If Jews voted Republican, they would point to that as evidence for the narrative.

Advocates of the anti-Jewish narrative sometimes attribute the (relative) lack of Jewish support for white nationalist movements to the Jewish group evolutionary strategy. In The Culture of Critique, MacDonald (1998: 80) writes: "Even if nationalist movements are anti-Semitic, as has often been the case, anti-Semitism should be irrelevant if these individuals are indeed completely deethnicized." MacDonald (2016) says that "there is a historical pattern where Jews have entered putatively nationalist movements and directed them towards positions that make them 'safe for the Jews', at the expense of developing a true sense of ethnic interests." He quotes his protégé, Andrew Joyce: "That Jews would try to co-opt, or attempt to derail, a potentially damaging movement does have many historical precedents." Joyce goes on to say that "Jews attempted to take key roles" in the German nationalist movement in 1860-1880 until, under the influence of nonJewish leaders, the "movement adopted an "Aryan clause." So if Jews want to join white nationalist movements as equals, they are accused of scheming to make the movements "safe for the Jews" and driven out. Then white nationalists ask why Jews don't support their movements. Haven't they answered their own question?

When given the opportunity, Jews have been overrepresented in non-anti-Semitic white nationalist movements, as MacDonald and Joyce inadvertently acknowledge. The one major white nationalist organization in the US that is not explicitly anti-Semitic is American Renaissance. Four-out-of-ten invited speakers at the first American Renaissance conference in 1994 were Jewish (Lawrence Auster, Michael Levin, Rabbi Mayer Schiller, and Eugene Valberg) (American Renaissance 2017), and many of its most prominent supporters were Jewish. However, Jewish support waned over the years as anti-Semitism crept in. Two of the original four Jewish speakers-Auster and Levin-later distanced themselves from the organization due to anti-Semitism (Auster 2006; Beirich and Potok 2006), though Levin's book, Why Race Matters, is still published by the New Century Foundation (which publishes American Renaissance) and sold on AmRen.com. An article in MacDonald's own journal, The Occidental Quarterly, reported in 2008 that “The 'Jewish question' surfaced in one guise or another in almost all of the speeches that were given at this year's American Renaissance Conference. It is a source of increasing tension" (Pyke 2008). The article concluded that "You do not pull the eleventh chair up to a table set for ten," metaphorically referring to a Jew trying to participate in a movement for white gentiles.

Many contemporary white nationalists strongly emphasize hostility to Jews. Mike Enoch-founder of the alt-right website "The Right Stuff"- expounds (in a nowdeleted YouTube video):

One thing I will say-no fucking Jews. No, no, no, no, no. None. Gone. If you really want to help the alt-right for real, give us all your money and move to 
Israel. Otherwise I don't believe you want to help us. That's literally it. There's one thing a Jew can do to help the alt-right if you want to: literally, all your money, all of it, every single fucking shekel. Give it to me and move to Israel. That's the only thing you can do. If you don't do that, you're not a Jew who wants to help the alt-right. Done and done, that's it, zero tolerance.

Counter-Currents editor Greg Johnson, who styles himself as more of an intellectual, writes: "Jews are not Europeans....[T]here is an inevitable conflict between Jewish and European interests and identity....[T]he organized Jewish community is the principal enemy...of every attempt to halt and reverse white extinction....Therefore, White Nationalism is inescapably anti-Semitic" (Johnson 2014). De facto altright leader Richard Spencer says that it would be an "insult" to "tell a Jew that he's a man of the West or a European," and "a European homeland...would be a European homeland" (Spencer 2016). In other words, Spencer wants a white ethnostate with no Jews allowed.

I want to reiterate that I am commenting on this phenomenon from a neutral scientific perspective. I'm not saying that Jews should be white nationalists, or recommending that gentiles adopt any particular attitude toward Jews. I'm simply pointing out that the obvious explanation for Jewish underrepresentation in white nationalist movements relative to other movements is that Jews aren't welcome. It is not necessary to postulate a "group evolutionary strategy."

\section{Conclusion}

Much of our social system is founded on the scientific premise that all groups (if not all individuals) are basically the same. The possibility that they are not the same raises difficult moral and political challenges (Anomaly and Winegard 2020; Cofnas 2020; Gottfredson 2005; Sesardić 2005: chapter 6; Warne 2020). The long-term success of humanity will depend on our ability to come to terms with reality, including controversial facts about group differences.

Combing through history books and newspapers to pick out examples of Jewish radicals while ignoring gentile radicals, and spinning unsupported tales about the nefarious motivations of the Jews, is not "race realism." The conflation of this activity with race realism has misled people, made it harder to bring legitimate but controversial science into the mainstream, and drawn attention away from important scientific questions about the actual origins of our political system. It has also made it harder to draw attention to bona fide wrongdoing by establishment Jewish leaders (Cofnas 2017), since they can frame any criticism as conspiracy theorizing and "anti-Semitism." Genuine realists have to fight a war on two fronts-against two narratives that are equally false.

Open Access This article is licensed under a Creative Commons Attribution 4.0 International License, which permits use, sharing, adaptation, distribution and reproduction in any medium or format, as long as you give appropriate credit to the original author(s) and the source, provide a link to the Creative Commons licence, and indicate if changes were made. The images or other third party material in this article 
are included in the article's Creative Commons licence, unless indicated otherwise in a credit line to the material. If material is not included in the article's Creative Commons licence and your intended use is not permitted by statutory regulation or exceeds the permitted use, you will need to obtain permission directly from the copyright holder. To view a copy of this licence, visit http://creativecommons.org/licen ses/by/4.0/.

\section{References}

American Renaissance. (2017). First American Renaissance conference (1994). https://www.amren.com/ archives/conferences/ar1994/. Accessed 3 Sept 2020.

Anomaly, J., \& Winegard, B. (2020). The egalitarian fallacy: Are group differences compatible with political liberalism? Philosophia, 48(2), 433-444.

Auster, L. (2006). Jared Taylor's refusal to condemn anti-Semitism. http://www.amnation.com/vfr/archi ves/005449.html. Accessed 3 Sept 2020.

Barry, E. (2018). In Sweden's preschools, boys learn to dance and girls learn to yell. The New York Times. https://www.nytimes.com/2018/03/24/world/europe/sweden-gender-neutral-preschools.html. Accessed 3 Sept 2020.

Baskin, A. (2016). How to help combat the "perpetual stranger status" of Jews of color. Union for Reform Judaism. https://urj.org/blog/how-help-combat-perpetual-stranger-status-jews-color. Accessed 3 Sept 2020.

Beauchamp, Z. (2016). Rent-a-Jew is an actual thing in Germany. And, amazingly, it's a good idea. Vox. https://www.vox.com/world/2016/12/15/13958618/rent-a-jew-germany. Accessed 3 Sept 2020.

Beirich, H., \& Potok, M. (2006). Schism over anti-Semitism divides key white nationalist group, American Renaissance. Intelligence Report. https://www.splcenter.org/fighting-hate/intelligence-repor t/2006/schism-over-anti-semitism-divides-key-white-nationalist-group-american-renaissance. Accessed 3 Sept 2020.

Canlorbe, G. (2019). A conversation with Kevin B. MacDonald. The Occidental Observer. https://www. theoccidentalobserver.net/2019/03/26/a-conversation-with-kevin-b-macdonald/. Accessed 3 Sept 2020.

Cochran, G., Hardy, J., \& Harpending, H. C. (2005). Natural history of Ashkenazi intelligence. Journal of Biosocial Science, 38(5), 659-693.

Cofnas, N. (2017). When accusations lose their bite. Quillette. https://quillette.com/2017/05/22/accus ations-lose-bite/. Accessed 3 Sept 2020.

Cofnas, N. (2018). Judaism as a group evolutionary strategy: A critical analysis of Kevin MacDonald's theory. Human Nature, 29(2), 134-156.

Cofnas, N. (2019). Is Kevin MacDonald's theory of Judaism "plausible”? A response to Dutton (2018). Evolutionary Psychological Science, 5(1), 143-150.

Cofnas, N. (2020). Research on group differences in intelligence: A defense of free inquiry. Philosophical Psychology, 33(1), 125-147.

Dershowitz, A. M. (2007). Foreward. In L. Lyons (Ed.), The Ethiopian Jews of Israel: Personal stories of life in the promised land (p. 10). Nashville: Jewish Lights Publishing.

Dutton, E. (2020). Making sense of race. Augusta: Washington Summit.

Gottfredson, L. S. (2005). What if the hereditarian hypothesis is true? Psychology, Public Policy, and Law, 11(2), 311-319.

Graham, H. D. (2002). Collision course: The strange convergence of affirmative action and immigration policy in America. New York: Oxford University Press.

Israel Ministry of Foreign Affairs. (2013). Law of Return 5710-1950. http://mfa.gov.il/mfa/mfa-archi ve/1950-1959/pages/law\%20of\%20return\%205710-1950.aspx. Accessed 3 Sept 2020.

Johnson, G. (2014). Vanguardism, vantardism, \& mainstreaming. Counter-Currents. https://www.count er-currents.com/2014/10/vanguardism-vantardism-and-mainstreaming/. Accessed 3 Sept 2020.

Kuhn, T. S. (1962). The structure of scientific revolutions. Chicago: University of Chicago Press.

Lucotte, G., \& Smets, P. (1999). Origins of Falasha Jews studied by haplotypes of the Y chromosome. Human Biology, 71(6), 989-993.

Lynn, R., \& Kanazawa, S. (2008). How to explain high Jewish achievement: The role of intelligence and values. Personality and Individual Differences, 44(4), 801-808. 
MacDonald, K. (1998). The culture of critique: An evolutionary analysis of Jewish involvement in twentieth-century intellectual and political movements. Westport: Praeger.

MacDonald, K. (2002). Preface to the first paperback edition. In The culture of critique: An evolutionary analysis of Jewish involvement in twentieth-century intellectual and political movements (pp. v-lxx). Bloomington, IN: 1st Books Library.

MacDonald, K. (2016). The alt right and the Jews. The Occidental Observer. https://www.theocciden talobserver.net/2016/09/17/the-alt-right-and-the-jews/. Accessed 3 Sept 2020.

MacDonald, K. (2018a). Jewish organizations had a role in 1965 act. The Wall Street Journal. https://www. wsj.com/articles/jewish-organizations-had-a-role-in-1965-act-1523374146. Accessed 3 Sept 2020.

MacDonald, K. (2018b). Reply to Nathan Cofnas. The Unz Review. https://www.unz.com/article/reply-tonathan-cofnas/. Accessed 3 Sept 2020.

Myers-JDC-Brookdale Institute. (2015). Israel's Ethiopian population: Progress and challenges. https ://brookdale.jdc.org.il/wp-content/uploads/2018/04/Israels_Ethiopian_Population_Progress_and_ Challenges_May_2015-US.pdf. Accessed 3 Sept 2020.

Niebuhr, G. (2001). Reform Judaism nears a guide to conversion. The New York Times. https://www.nytim es.com/2001/06/27/us/reform-judaism-nears-a-guide-to-conversion.html. Accessed 3 Sept 2020.

Pew Research Center. (2013). A portrait of Jewish Americans: Findings from a Pew Research Center survey of U.S. Jews. https://www.pewresearch.org/wp-content/uploads/sites/7/2013/10/jewish-ameri can-full-report-for-web.pdf. Accessed 3 Sept 2020.

Pinker, S. (2002). The blank slate: The modern denial of human nature. New York: Penguin Books.

Pyke, M. (2008). American Renaissance conference: The eleventh chair. The Occidental Observer. https ://www.theoccidentalobserver.net/2008/02/23/amren-eleventh-chair/. Accessed 3 Sept 2020.

Riley, N. S. (2013). 'Til faith do us part: How interfaith marriage is transforming America. Oxford: Oxford University Press.

Sales, B., \& Adkins, L. E. (2020). 'I think it's Israel': How Orthodox Jews became Republicans. Jewish Telegraphic Agency. https://www.jta.org/2020/02/03/politics/i-think-its-israel-how-orthodox-jewsbecame-republicans. Accessed 3 Sept 2020.

Sesardić, N. (2005). Making sense of heritability. Cambridge: Cambridge University Press.

Sesardić, N. (2018). Is racial profiling a legitimate strategy in the fight against violent crime? Philosophia, 46(4), 981-999.

Sharon, J. (2019). 37\% of immigrants in last eight years not Jewish, updated data show. The Jerusalem Post. https://www.jpost.com/israel-news/37-percent-of-immigrants-in-last-eight-years-not-jewis h-updated-data-show-612008. Accessed 3 Sept 2020.

Söderlund, T., \& Madison, G. (2015). Characteristics of gender studies publications: A bibliometric analysis based on a Swedish population database. Scientometrics, 105(3), 1347-1387.

Sokol, S. (2019). Why most new immigrants to Israel aren't considered Jewish. The Times of Israel. https ://www.timesofisrael.com/why-most-new-immigrants-to-israel-arent-considered-jewish/. Accessed 3 Sept 2020.

Spencer, R. B. (2016). The alt-right press conference I Richard Spencer, Peter Brimelow \& Jared Taylor. https $: / / w w w . y o u t u b e . c o m / w a t c h ? v=a J W L j R K 2 S R o \& f e a t u r e=y o u t u . b e \& t=4095$. Accessed 3 Sept 2020.

Tawat, M. (2019). The birth of Sweden's multicultural policy. The impact of Olof Palme and his ideas. International Journal of Cultural Policy, 25(4), 471-485.

Traub, J. (2016). The death of the most generous nation on earth. Foreign Policy. https://foreignpolicy. com/2016/02/10/the-death-of-the-most-generous-nation-on-earth-sweden-syria-refugee-europe/. Accessed 3 Sept 2020.

Warne, R. T. (2020). In the know: Debunking 35 myths about human intelligence. Cambridge: Cambridge University Press.

Winegard, B., Winegard, B., \& Boutwell, B. (2017). Human biological and psychological diversity. Evolutionary Psychological Science, 3(2), 159-180.

Winegard, B., Winegard, B., \& Anomaly, J. (2020). Dodging Darwin: Race, evolution, and the hereditarian hypothesis. Personality and Individual Differences, 160, 109915.

Publisher's Note Springer Nature remains neutral with regard to jurisdictional claims in published maps and institutional affiliations. 